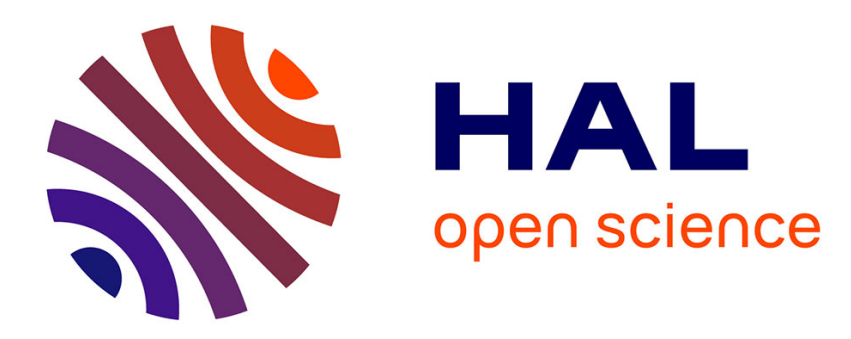

\title{
A radial oscillating collimator for small position sensitive detectors
}

J. Bouillot, J. Torregrossa

\section{To cite this version:}

J. Bouillot, J. Torregrossa. A radial oscillating collimator for small position sensitive detectors. Revue de Physique Appliquée, 1984, 19 (9), pp.799-800. 10.1051/rphysap:01984001909079900 . jpa00245264

\section{HAL Id: jpa-00245264 https://hal.science/jpa-00245264}

Submitted on 1 Jan 1984

HAL is a multi-disciplinary open access archive for the deposit and dissemination of scientific research documents, whether they are published or not. The documents may come from teaching and research institutions in France or abroad, or from public or private research centers.
L'archive ouverte pluridisciplinaire HAL, est destinée au dépôt et à la diffusion de documents scientifiques de niveau recherche, publiés ou non, émanant des établissements d'enseignement et de recherche français ou étrangers, des laboratoires publics ou privés. 


\title{
A radial oscillating collimator for small position sensitive detectors
}

\author{
J. Bouillot and J. Torregrossa \\ Institut Laue-Langevin, 156X, 38042 Grenoble Cedex, France
}

\begin{abstract}
Résumé. - Ce papier décrit un collimateur radial oscillant étudié pour réduire le bruit de fond et la diffraction parasite venant de l'environnement de l'échantillon. Les premiers résultats sont présentés.
\end{abstract}

Abstract. - A radial oscillating collimator built for reducing background and parasitic scattering from the sample environment on the diffractometer D2 at the ILL is described in this paper. First results are presented.

Most of diffraction experiments on diffractometers using position sensitive detectors (PSD) require sample environments (furnace, cryostat, etc.) which produce parasitic scattering. Moreover, the air on the way of the direct beam gives rise to an additional background. The first solution was the use of high, low or room temperature devices mounted with a vanadium cylinder near the sample and a large vacuum chamber around. The vanadium only contributes to the background, and the scattering from the material of the chamber (usually $\mathrm{Al}$ ) crossed by the direct beam is catched by cadmium sheets located in well-chosen areas inside (Fig. 1a). The vacuum avoids air scattering. This simple solution which is independent of the size of the detector has unfortunately some disadvantages :

1) background from the vanadium,

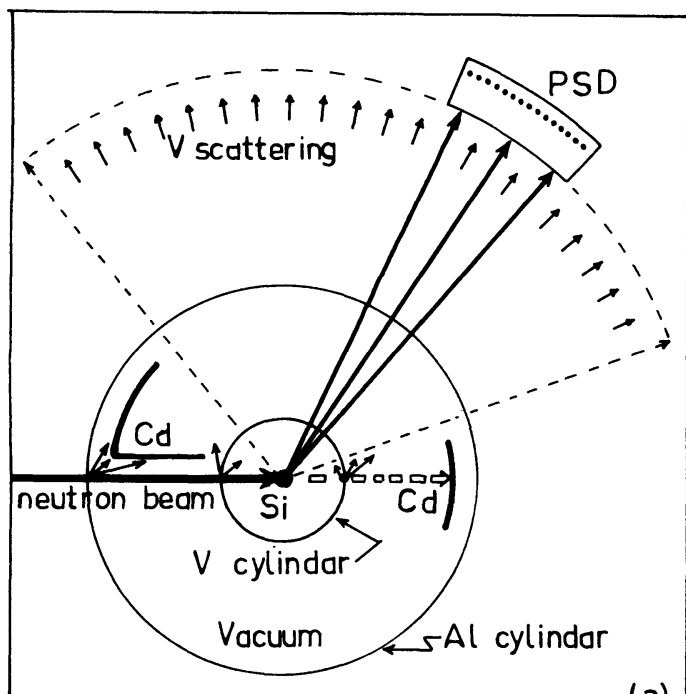

(a)
2) not available for special sample environments (very high temperature, pressure cells, cryomagnet) which are more and more required,

3) particular sample environment devices which cannot be used on other instruments.

Therefore an other solution must be found to overcome those difficulties. In the same context, Soller collimators have been used in diffraction instruments (with single detectors) for some decades to limit the irradiated sample volume viewed by the detector and reduce the detection of off-centre parasitic scattering. In the case of PSD, a development at the ILL, the Radial Oscillating Collimator (ROC) is a diffracted beam collimator of revised geometry, designed to suppress off-sample parasitic scattering without perturbing the sample scattering or modifying the reso-

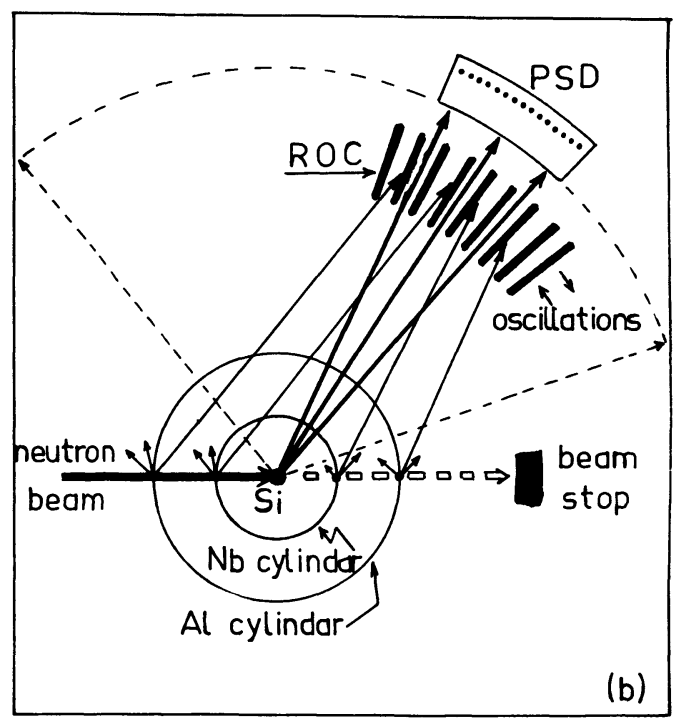

Fig. 1. - a) Sketch of the previous solution. b) Sketch of the ROC solution. 
lution. The first two versions were adapted to the low temperature Weissenberg camera D12 at ILL [1] and to the very high temperature furnace $\left(2500^{\circ} \mathrm{C}\right)$ for neutron powder diffraction [2].

ROC is also being installed in the time-of-flight spectrometer IN6 at ILL to reduce air scattering and parasitic scattering from a beryllium filter [3].

The idea was to fix such a ROC to the small PSD of the diffractometer D2. Figure $1 \mathrm{~b}$ shows a projection of the collimator geometry. The rigid foils are made from stainless steel band of $0.1 \mathrm{~mm}$ thickness spray painted on both sides with gadolinium oxide paint to obtain a total thickness of about $0.3 \mathrm{~mm}$. The collimator divergence (\# $6 \mathrm{deg}$ ) has been chosen for cutting Bragg reflections at $2 \theta>30 \mathrm{deg}$ from material at a distance to the sample larger than $5 \mathrm{~cm}$. To equalize shadows cast by the finite blade thickness, the collimator must be oscillated through an angle equivalent to a small number of whole blade spacings with a linear angular velocity. This is done using a rotating heart-shaped cam (spiral of Archimedes) acting tangentially to the collimator.

This ROC was tested by using a cylindrical sample of powdered silicon ( $8 \mathrm{~mm}$ diameter) at the centre of a cylinder made from vanadium $(0.5 \mathrm{~mm}$ thick and radius of $30 \mathrm{~mm}$ ) or/and at the centre of an aluminium cylinder ( $2 \mathrm{~mm}$ thick and radius of $75 \mathrm{~mm}$ ). The wavelength was $1.22 \AA$ and the beam divergence was 30 minutes. Results are summarized on figure 2 and are very promising for the future. Indeed, the signal/noise

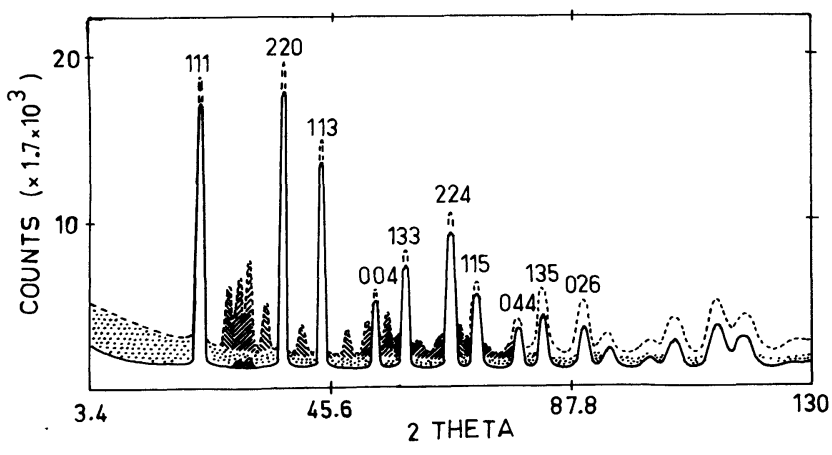

Fig. 2. - Diffraction patterns from a powdered silicon sample on the diffractometer D2. ----- pattern without ROC, I/I/I// Bragg reflections from Nb, IIIIII Bragg reflections from $\mathrm{Al}, \because \vdots$ air scattering (for example), $h k l$ Bragg reflections from $\mathrm{Si}$, — pattern with $\mathrm{ROC}$.

ratio is much better with the $\mathrm{ROC}$. and the only parasitic Bragg reflection coming from the niobium element is the one at lowest $2 \theta$ angle which is, in any case, considerably reduced.

The advantage of this ROC is the possibility of using any sample environment on the diffractometer. Even with usual furnace or cryostat, the result is much better than before with the previous solution. The problem now is to build such a ROC for a large PSD. Technical difficulties with the mechanical accuracy and stability are not yet solved, but can surely be overcome.

References

[1] Hohlwein, D. and Wright, A. F., J. Appl. Crystallogr. 14 (1981) 82

[2] W'right. A. F.. Bernferon. M. and Heathman. S. P.. Nucl. Instrum. Methods 180 (1981) 655.

[3] Dianoux, A. J. and Blanc, Y., Internal ILL report 83BL21G. 